\section{Assessing Susceptibility of Carrot Roots to Bacterial Soft Rot}

\author{
Barbara Michalik ${ }^{1}$, Philipp W. Simon', and Warren H. Gabelman ${ }^{3}$ \\ Department of Horticulture, University of Wisconsin, Madison, WI 53703
}

Additional index words. Daucus carota, disease screening, breeding lines, cultivars

\begin{abstract}
Four methods for screening carrot ( Daucus carota L.) germplasm for resistance to bacterial soft rot were compared. There were differences in resistance among strains, with most severe damage caused by Erwinia carotovora pv. carotovora SR 394 (L.R. Jones) Holland and Erwinia carotovora pv. atroseptica SR 159 (van Hall) Jennison. Inoculation of cross-sectional root slices with bacteria applied in suspensionsoaked paper disks produced the most consistent response. The severity of disease damage was proportional to bacterial suspension concentration. With the development of a standard screening method, it may be possible for breeders to breed carrots with reduced susceptibility to soft rot.
\end{abstract}

Erwinia carotovora is the causal agent of soft rot of carrot. This disease causes severe root losses of carrot, mainly during postharvest storage, but also in the field late in the growing season. The soft-rot bacterium is especially destructive on carrot at high temperature and high humidity (Segall and Dow, 1973). The soft-rot Erwinia spp. occur worldwide and are usually present in soil and water. They may also be disseminated by insects (Phillips and Kelman, 1982). Because most soft-rot Erwinia spp. attack many crops and are not host-specific, it is not uncommon to isolate more than one species or

Received for publication 10 June 1991. Accepted for publication 27 Mar. 1992. Research supported by College of Agricultural and Life Science, Univ. of Wisconsin, Madison; U.S. Dept. of Agriculture, Agricultural Research Service; Campbell's Soup Co.; and PetoSeed Co. The cost of publishing this paper was defrayed in part by the payment of page charges. Under postal regulations, this paper therefore must be hereby marked advertisement solely to indicate this fact.

${ }^{1}$ Visiting Scientist. Current address: Agricultural Univ., Krakow, Poland.

${ }^{2}$ Research Geneticist and Professor, U.S. Dept. of Agriculture, Agricultural Research Service.

${ }^{3}$ Professor. pathovar from a diseased plant (Perombelon and Kelman, 1980).

The highest losses caused by soft-rot $E r$ winia spp. occur on vegetatively reproduced plants, such as potato, carnation, and chrysanthemum (Otazu and Secor, 1981). Extensive research has focused on the soft rot/ blackleg complex in potato (Solanum tuberosum L.). Little attention has been directed to bacterial soft rot in carrot. Our study evalcarrot inbreds W234B and W261B. uated different methods of inoculating carrots to establish a simple, reliable test for evaluating breeding materials for possible resistance to Erwinia.

Bacterial strains used were Erwinia carotovora pv. carotovora (Ecc SR 319 and SR 392) and Erwinia carotovora pv. astroseptica (Eta SR 159), provided by Arthur Kelman, Univ. of Wisconsin, Madison, and a new strain Ecc SR 394, isolated from rotted carrot roots grown on organic soil in Wisconsin. The latter strain was identified as $E$. carotovora pv. carotovora based on an $\alpha$ methyl-glucoside-containing medium as outlined by Cuppels and Kelman (1974).

All bacterial strains were maintained as stock suspensions in distilled water at room temperature. Bacteria were transferred to casamino-peptone glucose (CPG) broth for inoculum preparation and incubated at $25 \mathrm{C}$ on a rotary shaker $(100 \mathrm{rpm})$ for $24 \mathrm{~h}$ to obtain cells in the log phase of growth. Bacteria were collected by centrifugation at $10,000 \times \mathrm{g}$ for $10 \mathrm{~min}$, then resuspended in sterile, deionized water. The concentration (colony-forming units per $1 \mathrm{ml}$ of bacterial suspension, cfu/ml) was adjusted by optical density with a Bausch and Lomb spectrophotometer (Rochester, N.Y.) at $620 \mathrm{~nm}$.

Genetic stocks tested in this experiment included inbred lines and open-pollinated

Table 1. Disease response of four Erwinia carotovora strains (Ecc SR) at three concentrations on

\begin{tabular}{lcccc}
\hline \hline \multirow{2}{*}{ Ecc SR } & & \multicolumn{3}{c}{$\begin{array}{c}\text { Inoculum concn } \\
\text { (cfu/ml) }\end{array}$} \\
\cline { 4 - 5 } 394 & Carrot & & $5 \times 10^{7}$ & $5 \times 105$ \\
\hline \multirow{3}{*}{159} & line & $3.5 \times 10^{8}$ & Disease score & \\
& W 234B & $3.8 \mathrm{ab}$ & $2.9 \mathrm{def}$ & $0.7 \mathrm{j}$ \\
319 & W 261B & $3.3 \mathrm{bc}$ & $2.3 \mathrm{bc}$ & $1.6 \mathrm{~h}$ \\
& W 234B & $3.6 \mathrm{ab}$ & $3.2 \mathrm{~cd}$ & $0.3 \mathrm{k}$ \\
392 & W 261B & $2.8 \mathrm{ef}$ & $2.2 \mathrm{~g}$ & $1.1 \mathrm{i}$ \\
& W 234B & $3.4 \mathrm{bc}$ & $3.3 \mathrm{bc}$ & $0.1 \mathrm{k}$ \\
& W 261B & $2.0 \mathrm{~g}$ & $1.3 \mathrm{hi}$ & $0.7 \mathrm{j}$ \\
& W 234B & $3.3 \mathrm{bc}$ & $3.1 \mathrm{cde}$ & $0.1 \mathrm{k}$ \\
\hline
\end{tabular}

${ }^{2}$ Mean of disease severity, where $0=$ no decay, $5=$ total decay.

'Mean separation among all values by Duncan's multiple range test, $P<0.05$. 


\section{Disease classes:}

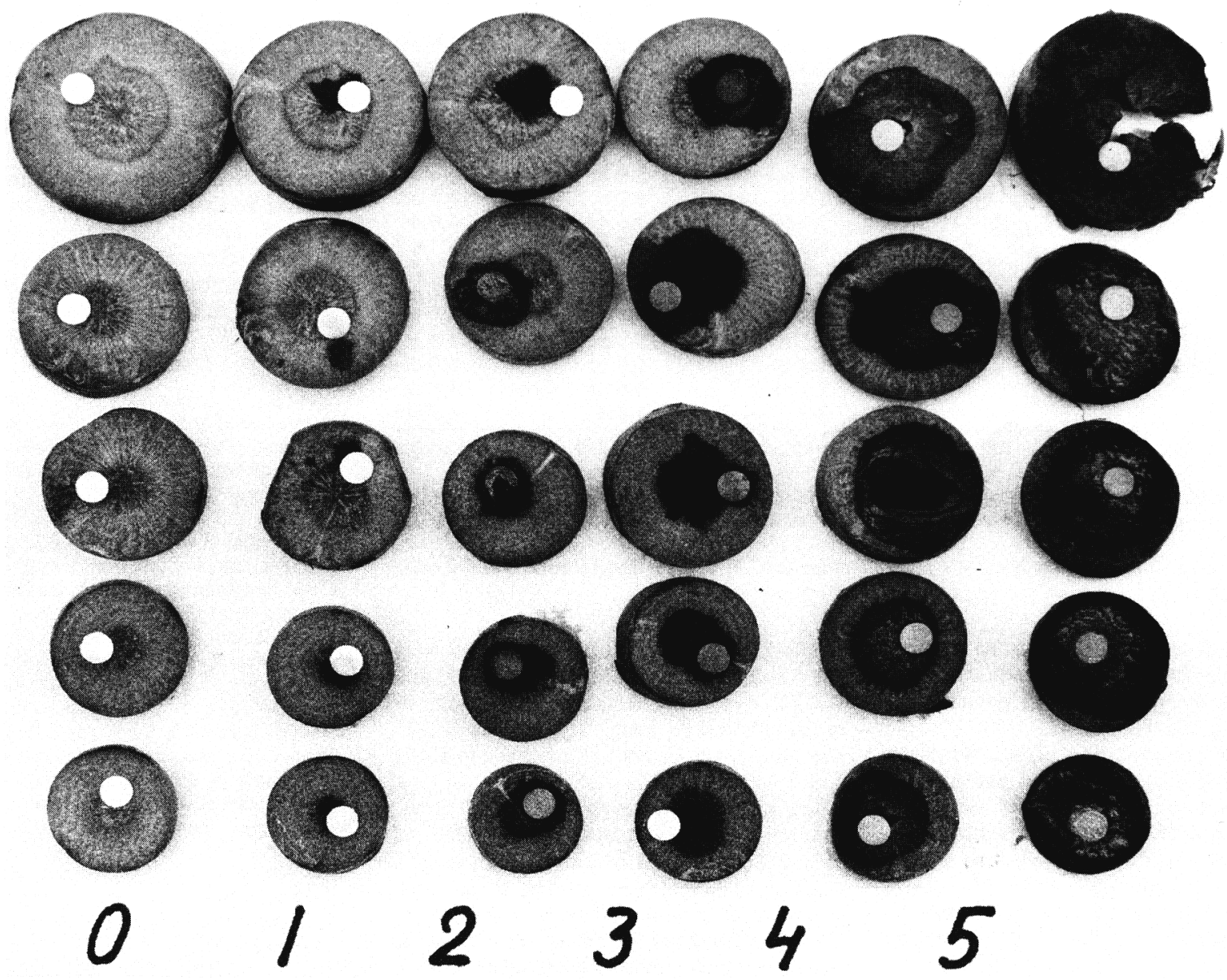

1. Disease classes for bacterial soft rot damage in carrot root slices as used to determine disease score.

cultivars. Except for storage and root part experiments described later, roots were grown on organic soil in commercial carrot fields in Wisconsin in the summer, harvested in August, and stored 1 to 3 weeks at 0 to $4 \mathrm{C}$ until testing. Root samples to be tested for resistance to soft rot were washed with tap water, surface-sterilized with $0.05 \%$ sodium hypochlorite $(\mathrm{NaOCl})$ for $40 \mathrm{~min}$ and $70 \%$ ethanol for $5 \mathrm{~min}$, rinsed in sterile water, and allowed to air-dry.

Four methods of inoculation were compared: A) The crown portion (about one-third of the root) with petioles trimmed to $2 \mathrm{~cm}$ was used. Two holes, $\approx 1 \mathrm{~mm}$ in diameter $\times 2 \mathrm{~cm}$ deep, were made in the root cambium region through the cut surface of the crown portion. Then $10 \mu 1$ of Erwinia suspension was injected into the holes with a syringe, one strain per hole. B) Same as method A, except the middle third of the root was used. Inoculation was always on the distal cut root surface. C) Cross-sectional, 5mm-thick slices of root were used. Disks of Whatman \#2 filter paper ( $5 \mathrm{~mm}$ in diameter) were soaked in bacterial suspension for at least $30 \mathrm{~min}$ and then placed on the proximal cut surface of the carrot slice over the cam- bium region. D) Root slices, $5 \mathrm{~mm}$ thick, were inoculated with $10 \mu \mathrm{l}$ of bacterial suspension placed on the freshly cut surface, without additional wounding.

After inoculation, carrot root samples were placed in plastic boxes $(40 \times 25 \times 5 \mathrm{~cm})$ lined with wet paper towel, sealed with plastic wrap, and placed in plastic bags. These inoculation chambers were incubated at $22 \mathrm{C}$ for 48 to $96 \mathrm{~h}$.

Soft-rot severity was determined on the basis of disease score, an estimate of the area decayed. A scale of 0 to 5 was used, where $0=$ no decay and $5=$ total decay (Fig. 1). To evaluate disease development for methods $\mathrm{A}$ and $\mathrm{B}$, roots were cut through the point of inoculation after $96 \mathrm{~h}$ of incubation. Disease response for methods C and D was evaluated after $48 \mathrm{~h}$.

Roots from one open-pollinated population (B951-1) and male-sterile and fertile (maintainer) counterparts of two inbred lines (B493 and B9304) were grown in Florida and California. Postharvest storage was at 4C in paper bags within non-sealed plastic bags. Seven roots of each entry were evaluated 2, 6, and 12 weeks after harvest. All roots were intact through the first 2 weeks of storage. Then, 14 roots were cut transversally at midsection and 14 left intact for each inbred line. These 28 roots of each stock were returned to storage. After 6 and 12 weeks of storage, seven each of the cut (both crown and top) and intact roots were screened. Root slices were inoculated (method C) with $E$. carotovora pv. carotovora SR 394 at a concentration of $5 \times 10^{7} \mathrm{cfu} / \mathrm{ml}$ inoculum.

Significant differences in disease development were found among strains of Erwinia on two carrot lines (Table 1). Ecc SR 394, freshly isolated from decaying carrots, produced the most severe tissue damage in this study, as it did on potatoes (Austin et al., 1988). Eta SR 159, isolated from potatoes, produced slightly less severe damage. Ecc strains SR 319 and SR 392 produced milder symptoms. Because of their greater pathogenic@, all subsequent experiments were done with Ecc SR 394 and Eta SR 159. All four $E$. carotovora strains at all concentrations incited a more severe response on carrot line W 261B than on W 234B. Differences in disease response among carrot lines were greater with the less pathogenic Erwinia strains and lower inoculum concentrations. There were no strain $\times$ line or strain $\times$ 
Table 2. Bacterial soft rot development in 15 carrot strains. $^{2}$

\begin{tabular}{|c|c|c|c|c|}
\hline \multirow[b]{2}{*}{ Strain } & \multicolumn{4}{|c|}{ Disease rating for four methods of infection ${ }^{y}$} \\
\hline & A & B & $\mathrm{C}$ & $\mathrm{D}$ \\
\hline \multicolumn{5}{|c|}{ Expt. 1} \\
\hline W77C & $0.5 \mathrm{ab}^{\mathrm{x}}$ & $0.5 \mathrm{~b}$ & $2.0 \mathrm{~b}$ & $2.5 \mathrm{~b}$ \\
\hline W97B & $1.0 \mathrm{a}$ & $2.3 \mathrm{a}$ & $3.0 \mathrm{a}$ & $2.8 \mathrm{~b}$ \\
\hline W266C & $0.8 \mathrm{a}$ & $1.6 \mathrm{a}$ & $3.2 \mathrm{a}$ & $3.3 \mathrm{a}$ \\
\hline WAYII & $0.2 \mathrm{~b}$ & $0.5 \mathrm{~b}$ & $2.3 \mathrm{~b}$ & $2.8 \mathrm{~b}$ \\
\hline \multicolumn{5}{|c|}{ Expt. 2} \\
\hline F524 & & $4.0 \mathrm{a}$ & $5.0 \mathrm{a}$ & $4.4 \mathrm{bc}$ \\
\hline B2302 & & $2.5 \mathrm{~b}$ & $4.2 \mathrm{~b}$ & $4.3 \mathrm{~cd}$ \\
\hline B5238 & & $3.0 \mathrm{~b}$ & $3.6 \mathrm{~d}$ & $4.0 \mathrm{de}$ \\
\hline B5316 & & $4.0 \mathrm{~d}$ & $4.7 \mathrm{a}$ & $4.3 \mathrm{c}$ \\
\hline B9695 & & $0.8 \mathrm{~d}$ & $2.9 \mathrm{e}$ & $2.5 \mathrm{f}$ \\
\hline $\mathrm{HCM}$ & & $1.8 \mathrm{c}$ & $3.6 \mathrm{~d}$ & $4.8 \mathrm{a}$ \\
\hline B493 & & $2.8 \mathrm{~b}$ & $3.8 \mathrm{~cd}$ & $3.9 \mathrm{e}$ \\
\hline B9304 & & $3.7 \mathrm{a}$ & $5.0 \mathrm{a}$ & 4.8 a \\
\hline Imperial Long Scarlet & & $1.3 \mathrm{~cd}$ & $4.0 \mathrm{bc}$ & $4.0 \mathrm{de}$ \\
\hline Waltham Hicolor & & $1.1 \mathrm{~cd}$ & $3.9 \mathrm{bc}$ & $4.0 \mathrm{de}$ \\
\hline Scarlet Nantes & & $3.0 \mathrm{~b}$ & $4.8 \mathrm{~d}$ & $4.7 \mathrm{ab}$ \\
\hline
\end{tabular}

${ }^{7}$ Erwinia strain Ecc SR 159, $5 \times 10^{7}\left(\mathrm{cfu} / \mathrm{ml}\right.$ used in Expt. 1; strain Ecc SR 394, $2.5 \times 10^{8} \mathrm{cfu} / \mathrm{ml}$ in Expt. 2.

${ }^{y}$ Mean of disease severity, where $0=$ no decay, $5=$ total decay. Methods A, B, C, and D described in the text. No development in noninoculated controls on sterile water-inoculated controls with any method.

${ }^{x}$ Mean separation in columns by Duncan's multiple range test, $P<0.05$. Experiments 1 and 2 were analyzed separately.

concentration interactions. Similar relationships among Erwinia spp., pathovars, and strains have been observed in potato (Lapwood et al., 1984).

Inoculum concentration effects were significant for a given carrot line and Erwinia strain in all cases, except for the two higher concentrations of the less pathogenic strains on the more susceptible carrot line. An inoculum concentration of $5 \times 10^{6} \mathrm{cfu} / \mathrm{ml}$ was also tested and found to induce disease severity comparable to the $5 \times 10^{7} \mathrm{cfu} / \mathrm{ml}$ concentration (data not presented).

Inoculation of carrot root slices with methods $\mathrm{C}$ and $\mathrm{D}$ resulted in a more severe disease response than when pathogen was injected into larger root sections using methods A and B (Table 2). Variation in response was also reduced with methods $C$ and $D$. Inoculation with soaked paper disks (method C) produced a response similar to that from a surface drop of inoculum (method D). Reduced disease severity was observed with crown inoculation (method A) than with midroot inoculation (method B). Similar reponses in soft-rot suseptibility have been reported in a comparison of apical and basal ends of potato tubers (Otazu and Secor, 1981). Methods B, C, and D gave similar rankings of disease response among four Univ. of Wisconsin inbreds, seven U.S. Dept. of Agriculture inbreds of diverse genetic background, and three open-pollinated varieties
(Table 2); however, HCM and B5238 were not consistent in their response. W77C and WAYII were most resistant by all methods of inoculation in Expt. 1, whereas B9695 was most resistant with all methods in Expt. 2.

Duration of postharvest storage had no effect on severity of tarot bacterial soft rot (data not presented). Results at 2, 6, and 12 weeks postharvest were similar, as has been observed in potato (Workman and Holm, 1984). Differences in response to Erwinia attack in potato depended on tuber storage condition before inoculation (Bartz and Kelman, 1984; Workman and Holm, 1984). In contrast, we noted that stored, intact and cut carrot roots yielded similar results. The root tip tended to be slightly more susceptible than the crown. method suitable for a carrot breeding program, the paper disk method (method $\mathrm{C}$ ) provides some advantages. When root slices are used to evaluate disease response of roots, seed production) is not damaged, as would happen in method $\mathrm{A}$, or in the method developed by Skadow (1978). Furthermore, several root slices can be obtained from a single root, enabling replicated screening from one plant. These use of a paper disk (method C) reduced drying of the bacterial suspension and maintained better conditions for infec-
In choosing an Erwinia soft rot screening the crown of the root (which is necessary for tion and disease development. In wounding and droplet inoculation (methods D and E), which are similar to the method used by Lebeda (1985), evaporation was a problem, which may have reduced the disease development. The observed variation between carrot lines suggests the possibility for genetic improvement of resistance to Erwinia in carrot. However, correlation of laboratory response with damage realized either in storage or the field remains to be demonstrated. To ensure accurate comparisons, roots grown, harvested, and stored together need to be contrasted. Genetic differences in response to Erwinia infection between carrot strains may then be determined.

\section{Literature Cited}

Austin, S., E. Lojkowska, M.K. Ehlenfeldt, A Kelman, and J. Helgeson. 1988. Fertile interspecific somatic hybrids of Solarium: A novel source of resistance to Erwinia soft rot. Phytopathology 78:1216-1220.

Bartz. J.A. and A. Kelman. 1984. Bacterial soft rot potential in washed potato tubers in relation to temperatures of tubers and water during simulated commercial handling practices. Amer. Potato J. 61:485-493.

Cuppels, D. and A. Kelman. 1974. Evaluation of selective media for isolation of soft-rot bacteria from soil and plant tissue. Phytopathology 64:468-475

Lapwood, D.H., P.J. Read, and J. Spokes. 1984. Methods for assessing the susceptibility of potato tubers of different cultivars to rotting by Erwinia carotovora subspecies atroseptica and carotovora. Plant Pathol. 33:13-20.

Lebeda, A. 1985. Response of certain carrot species (Daucus carota) to artificial inoculation by Erwinia carotovora subsp. carotovora. EUCARPIA Root Vegetable Symp., Olomouc, Czechoslovakia. p. 82-88.

Otazu, V. and G.A. Secor. 1981. Soft rot susceptibility of notatoes with high reducing sugar content. Phytopathology 11:290-295.

Perombelon, M.C.M. and A. Keiman. 1980. Ecology of the soft rot erwinias. Annu. Rev. Phytopathol. 18:361-87.

Phillips, J.A. and A. Kelman. 1982. Direct fluorescent antibody stain procedure applied to insect transmission of Erwinia carotovora. Phytopathology 72:898-901.

Segall, R.H. and A.T. Dow. 1973. Effects of bacterial contamination and refrigerated storage on bacterial soft rot of carrots. Plant Dis. Rpt. 57:896-899.

Skadow, K. 1978. Eine objektive, rationelle Methode der Resistenzprüfung von Möhren gegen Erwinia carotovora (Jones) Bergey et al. var. carotovora Dye. Arch. Phytopathol. Pflanzenschutz 14:27-31.

Workman, M. and D.G. Holm. 1984. Potato clone variation in blackspot and soft rot susceptibility, redox potential, ascorbic acid, dry matter and potassium. Amer. Potato J. 61:723-733. 